\title{
Developing the technology of non-stationary treatment through the example of the deposit of Severnye Buzachi
}

\author{
Almukhametova Elvira Maratovna \\ Ufa State Petroleum Technological University, \\ Branch of the University in the City of Oktyabrsky, Russian Federation \\ elikaza@mail.ru
}

\begin{abstract}
In the last few years the research on efficiency of nonstationary treatment technology has been conducted at high-viscosity index oil field of Severnye Buzachi (Republic of Kazakh). The obtained results reveal that the technology of non-stationary flooding is efficient when developing reservoirs with high-viscosity index oil. However, in order to maintain permanent high technological efficiency it is necessary to modify the technology of non-stationary treatment continually since this technology has such characteristic feature as quick "ageing".

The further investigation into the issue how to apply the technology of non-stationary flooding efficiently can be carried out in two directions: to use non-stationary flooding for new pools with different porosity and permeability properties as well as to vary technological parameters of non-stationary flooding (including combination with other technologies) at sites where this technology has already been applied. At the deposit of Severnye Buzachi both approaches are used.

Positive experience of applying the technology of non-stationary flooding in combination with the technology of changing filtration flow direction at the pool of the seventh block of the deposit of Severnye Buzachi allows us to recommend using this technology for new pools.
\end{abstract}

Keywords - wellsite, high-viscosity index oil, non-stationary flooding, filtration flow direction change, oil production rate, water cut, reservoir pressure maintenance, well injection capacity

\section{INTRODUCTION}

Nowadays developing the production facilities of the deposit of Severnye Buzachi faces the challenge when stabilization of oil production only at the expense of extensive development of oil-field exploitation system (drilling new boreholes) is becoming insufficient. The experiments with applying technologies for oil recovery enhancement conducted by the license holder at the deposit allowed determining the technologies which have a high level of success. Nonstationary flooding is one of these technologies.

Non-stationary flooding has been applied at the deposit of Severnye Buzachi for more than seven years. During this period the technology has earned the reputation of an efficient and inexpensive method for oil recovery enhancement. Practically all sites where non-stationary flooding was applied showed the quality improvement of oil displacement. This fact is a convincing proof of non-stationary treatment efficiency. Applying cyclic water floods for high-viscosity oil pools with reservoirs having cavernosity of different nature is a new stage in developing non-stationary flooding.
There are a lot of problems associated with oil recovery from a reservoir with permeability variations. These problems become more complicated when exploiting high-viscosity index oils exhibiting structural and mechanical properties [1]. However, as it was shown [2], if oil exhibits structural and mechanical properties, non-stationary flooding can enhance oil recovery since it allows increasing pressure gradients at the border of "water flooded layer - oil saturated layer".

Non-stationary flooding technology applied at a nonstationary flooding site of the seventh block of the first production facility was invariable (cyclic water flood). It resulted in decreasing its efficiency. At the beginning (in 2009-2010) the specific effect of the technology was 136 tons/(well*month). By 2012 this value decreased up to 26 tons/(well*month) $[1,2]$.

\section{MATERIALS AND METHODS}

The obtained results, mentioned in the article, have been corroborated by applying hydro-dynamic simulators which were tested and recommended to be used in oil industry. Analysis methods with applying personal computers were used while processing field data. The developed recommendations have been confirmed by field test runs with positive operational benefit.

The results revealed in the paper were used when planning and implementing the program of non-stationary flooding at the first production facility of the seventh block (central part) at the deposit of Severnye Buzachi [3].

\section{METHOD CONTENT AND ASSESSMENT OF ITS EFFICIENCY}

The adoption of complex technology of non-stationary flooding (NSF) with the technology of filtration flow direction change (CFFD) in 2013 allowed increasing the technology efficiency sufficiently. Under these circumstances, the specific effect increased up to 83 tons/(well*month) $[5,6]$.

The next step in order to develop NSF technology at the given pool was the program design of applying non-stationary flooding on a year-round basis.

In winter period of 2014-2015 non-stationary effect was prolonged at the expense of organized restriction of well injection capacity according to their groups. Full cyclic water 
flood with halting some groups of injection wells started in April 2015.

In warm period of 2015 non-stationary flooding combined with CFFD was started on $3 d$ April by halting the injection wells of northern and central rows. In seven days the injection wells of northern and central rows were activated while the injection wells of eastern and western rows were halted. Symmetric cycles when dead time of the injection wells was equal to their running time were used $[4,7]$.

Figure 1 shows the dynamics of the development parameters of the pool. It is much in evidence that by the beginning of implementing NSF in 2014 the dynamics of the development parameters was characterized by descending oil production rate and growing water cut. In April 2014 water cut accounted for $89.4 \%$. The average monthly oil production rate decreased to 6.2 tons per day while the liquid rate was 58 tons per day. The average monthly injection capacity was $123 \mathrm{~m}^{3}$ per day.

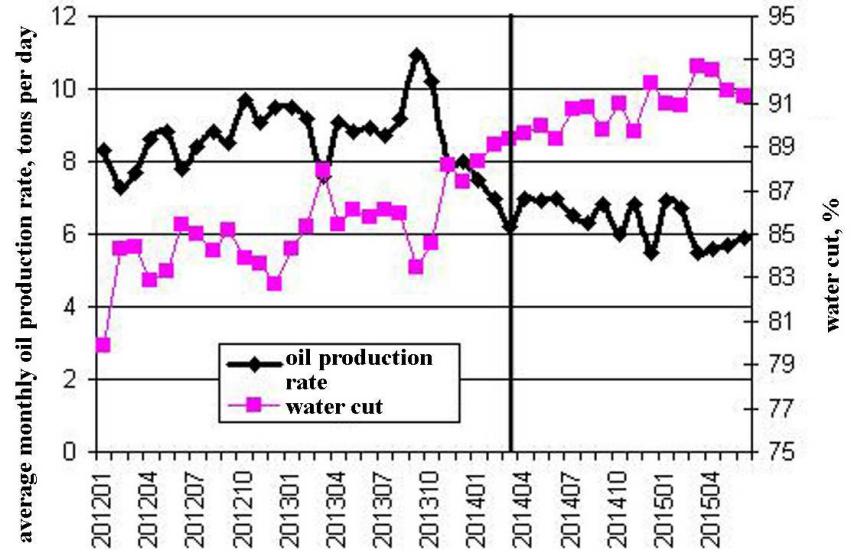

year, month

Fig. 1. The dynamics of the average monthly oil production rate and water cut at the central site of the seventh block for the last 3 years. The first production facility of the deposit of Severnye Buzachi.

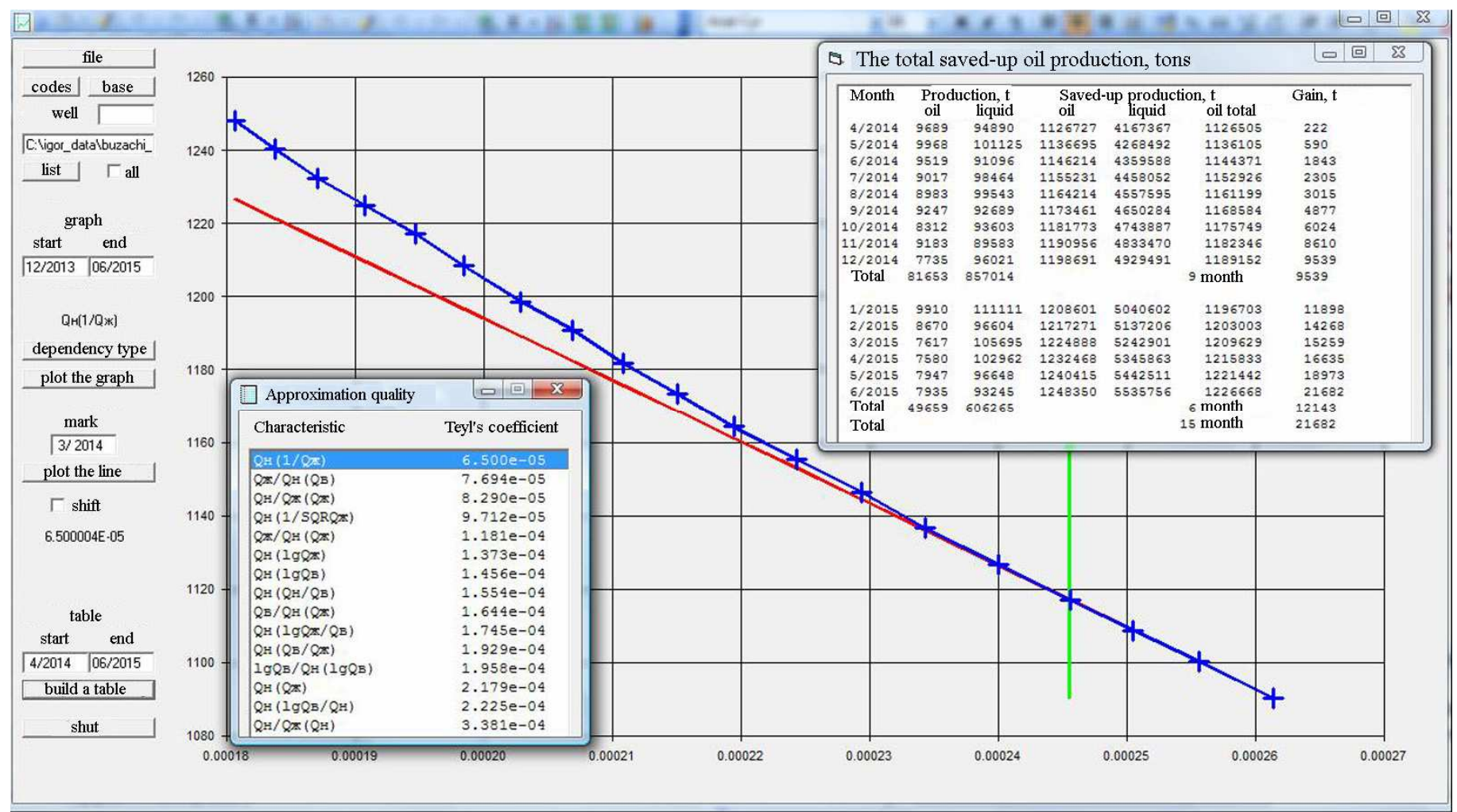

Fig. 2. Defining the technological benefit from applying NSF+ CFFD technology at the pool of non-stationary flooding of the seventh block of the first production facility. The green line shows the beginning of applying the technology in 2014 .

The calculation of technological efficiency of NSF+ CFFD has been made on the base of water flood displacement characteristics (Fig. 2). The calculation results are represented in Table 1. The average effect from NSF in 2014-2015 accounted for 15000 tons of incremental oil production. It is worth noting that in comparison with the results obtained by applying non-stationary flooding at the deposit in 2013 the effect value is considerably lower [10,12].
The efficiency analysis of the influence of NSF+ CFFD technology applied on the firm and infill wells reveals that maximum specific effect falls on infill wells (see Table 2, Figure 2a) 
TABLE I. THE TECHNOLOGICAL BENEFIT FROM APPLYING NSF+CFFD TECHNOLOGY AT THE POOL OF THE FIRST PRODUCTION FACILITY IN 2014-2015

\begin{tabular}{|l|l|l|l|}
\hline $\begin{array}{c}\text { water flood } \\
\text { displacement } \\
\text { characteristic }\end{array}$ & $\begin{array}{c}\text { technological } \\
\text { benefit value, } \\
\text { tons }\end{array}$ & $\begin{array}{c}\text { effect length, } \\
\text { month }\end{array}$ & $\begin{array}{c}\text { Theil index, relative } \\
\text { unit }\end{array}$ \\
\hline Он(1/Ож) & 21682 & 15 & $6.50 \mathrm{E}-05$ \\
\hline $\mathrm{Q}>\mathrm{K} / \mathrm{QH}(\mathrm{QB})$ & 15803 & 15 & $7.69 \mathrm{E}-05$ \\
\hline $\mathrm{Q}(1 / \mathrm{SQR}(\mathrm{Q}))$ & 12629 & 15 & $9.71 \mathrm{E}-05$ \\
\hline Ож/Он(Ож) & 8680 & 15 & $1.18 \mathrm{E}-04$ \\
\hline Он(1дОжЮв) & 16555 & 15 & $1.75 \mathrm{E}-04$ \\
\hline $\begin{array}{l}\text { average based on } \\
\text { the three best ones }\end{array}$ & 15070 & 15 & \\
& & & \\
\hline
\end{tabular}

TABLE II. EFFECT DISTRIBUTION FROM APPLYING NSF+CFFD TECHNOLOGY ACCORDING TO FIRM AND INFILL WELLS

\begin{tabular}{|l|c|c|c|}
\hline \multicolumn{1}{|c|}{ well stock } & firm & infill & total \\
\hline number of wells & 12 & 15 & 27 \\
\hline $\begin{array}{l}\text { overall effect, } \\
\text { tons per well }\end{array}$ & 2741.0 & 15441 & 18182 \\
\hline $\begin{array}{l}\text { specific effect, } \\
\text { tons per well }\end{array}$ & 228.4 & 1029.4 & 673.4 \\
\hline
\end{tabular}

Effect evaluation according to joint application of "optimization" technology and non-stationary flooding technology revealed that the wells where complex measures were used have a lower specific effect in comparison with the wells which were only subject to non-stationary flooding (Table 3, Figure 3b)

TABLE III. EFFECT EVALUATION FROM APPLYING NSF+ CFFD TECHNOLOGIES ACCORDING TO WELLS WITH AND WITHOT OPTIMIZATION

\begin{tabular}{|c|c|c|c|c|}
\hline $\begin{array}{c}\text { Kind of } \\
\text { geological and } \\
\text { technical } \\
\text { actions }\end{array}$ & $\begin{array}{c}\text { Overall } \\
\text { effect, } \\
\text { tons }\end{array}$ & $\begin{array}{c}\text { Number of } \\
\text { wells }\end{array}$ & $\begin{array}{c}\text { Specific } \\
\text { effect, } \\
\text { tons per } \\
\text { well }\end{array}$ & $\begin{array}{c}\text { Fraction of } \\
\text { unsuccessful } \\
\text { wells in a } \\
\text { pool, unit } \\
\text { fraction }\end{array}$ \\
\hline $\begin{array}{c}\text { Optimization + } \\
\text { NSF }\end{array}$ & 7685 & 14 & 549 & 0,21 \\
\hline NSF & 10497 & 13 & 807 & 0,08 \\
\hline
\end{tabular}

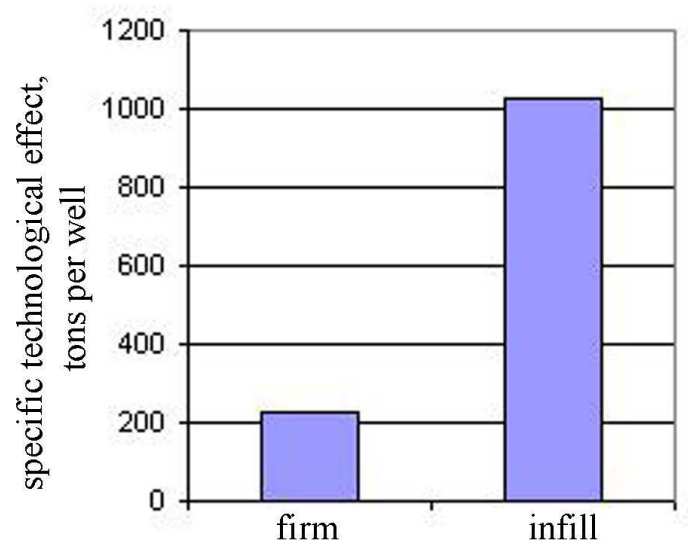

a

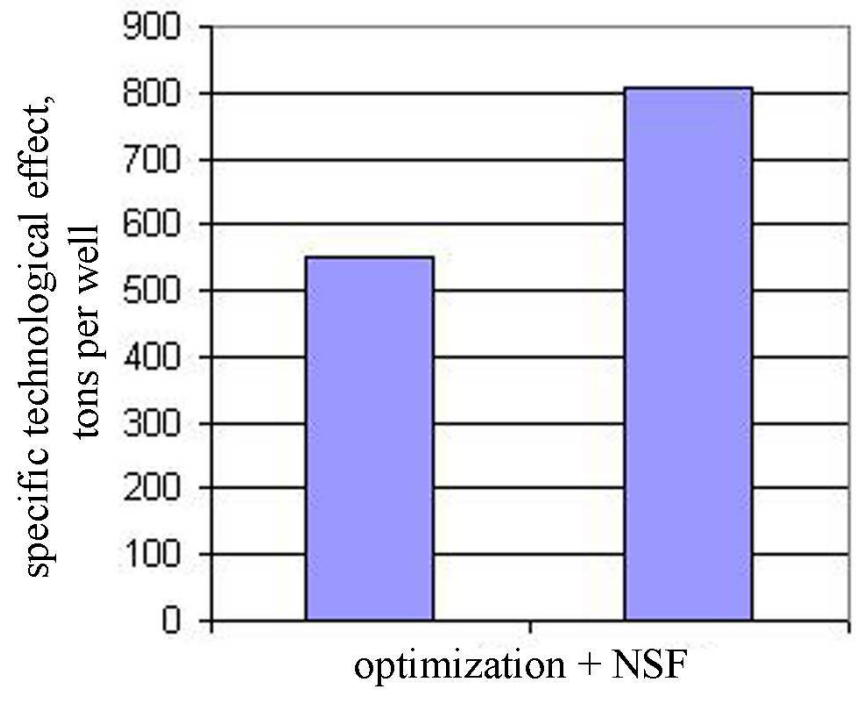

b

Fig. 3. Effect distribution from applying NSF+ CFFD technologies according to: a) firm and infill wells, b) wells with or without applying optimization

\section{CONCLUSION}

The conducted analysis of applying NSF+ CFFD technologies at the pool of the seventh block of the first production facility allows making important statements [9].

1. Changing the non-stationary treatment technology running for a long time allows increasing the efficiency of NSF.

2. Adopting all-year-round schedule of NSF allows slowing down the growth rates of water cut and oil production rate decrease.

3. The infill wells react more effectively to non-stationary flooding which is connected with a) closer location of these wells to the acting injection wells, b) higher density of remaining oil reserves located near infill wells.

4. Applying "optimization" technology (in fact, forcing fluid withdrawals) in combination with non-stationary flooding results in efficiency decrease of non-stationary flooding.

5. At the concerned pool of non-stationary flooding of the seventh block the NSF+ CFFD technology applied in 20132015 starts decreasing its efficiency. It requires further modification of the non-stationary flooding technology.

6. In order to develop non-stationary flooding technology further it is necessary to shift highly watered high-output exploitation wells into periodic operating duty $[8,11]$.

Intermittent exploitation well operation.

The shift of highly watered exploitation wells into periodic operating duty is supposed to solve the following problems:

1. The halt of some exploitation wells allows changing the direction of injected water flow.

2. Halting a number of exploitation wells will allow increasing the reservoir pressure at their pool which leads to increasing the pressure gradient in recovery zone, as a result the fractional oil content in the produced fluid will be increased (due to intensification). 
3. In addition to the above, the produced water capacity decreases significantly.

4. The reservoir pressure in the oil pool increases all in all.

\section{References}

[1] Ali J. Yazdani, B. MainiBrij, Effect of Drainage Height and Grain Size on the Convective Dispersion in the Vapex Process: Experimental Study, SPE paper 89409 presented at the 2004 SPE/DOE Fourteenth Symposium on Improved Oil Recovery held in Tulsa, Oklahoma, U.S.A., 17-21 April 2004.

[2] H. Zhang, B. Bai, Preformed Particle Gel Transport through Open Fractures and its Effect on Water Flow, SPE, 129908, 2010.

[3] S. A. Zhdanov et al. Application of Foam for Gas and Water Shut-off: Review of Field Experience, SPE 36914-MS, 377 - 388, 1996.

[4] I.V. Vladimirov, E.M. Veliyev, E.M. Almuhametova, Complex technology heat non-stationary flooding for periodic operation of producing wells. NTG «Problemy sbora, podgotovki i transporta nefti i nefteproduktov, Vol. 2 (96), pp. 15-16, 2014.

[5] I.V. Vladimirov, E.M. Veliyev, E.M. Almuhametova, The use of nestatsionarnaya on deposits of heavy oil collector with dual permeability. Theory. NTG «Problemy sbora, podgotovki i transporta nefti i nefteproduktov», Vol. 4 (98), pp.16-2, 20145.

[6] V.Sh. Mukhametshin, Yu.V. Zeigman, and A.V. Andreev, "Rapid assessment of deposit production capacity for determination of nanotechnologies application efficiency and necessity to stimulate their development," (in Russian), Nanotechnologies in Construction, vol. 9, no. 3, pp. 20-34, 2017. DOI: 10.15828/2075-8545-2017-9-3-20-34.

[7] R.T. Akhmetov, V.V. Mukhametshin, A.V. Andreev, and Sh.Kh. Sultanov, "Some testing results of productive strata wettability index forecasting technique," SOCAR Proceedings, Vol. 4, pp. 83-87, 2017. DOI: $10.5510 / O G P 20170400334$.

[8] V.V. Mukhametshin and R.R. Kadyrov, "Influence of nanoadditives on mechanical and isolating properties of cement-based compositions," (in Russian), Nanotechnologies in Construction, vol. 9-6, pp. 18-36, 2017. DOI: $10.15828 / 2075-8545-2017-9-6-18-36$.

[9] I.V. Vladimirov, E.M. Almukhametova, Non-stationary thermal effects in the development of high-viscous oil deposits.Geology, Geophysics and development of oil and gas fields, Vol. 4, pp. 23-27, 2016.

[10] I.V. Vladimirov, E.M. Almuhametova, E.M. Veliyev, Conditions of the effective use of hot water flooding for development of heavy oil deposits with non-uniform permeability, NeftyanoeKhozyaystvo- Oil Industry, Vol. 9, pp. 62-65, 2016.

[11] E.M. Almukhametova, A.V. Akimov, S.V. Kalinina, I.F. Fatkullin, I.A. Gizetdinov, Efficiency of preliminary discharge of stratum water in Tuymazinskoe oil field, IOP Conference Series: Earth and Environmental Science, Vol. 87- 6, 062001, 2017.

[12] E.M. Almukhametova, I.A. Gizetdinov, E.T. Kilmamatova, A.V. Akimov, S.V. Kalinina, I.F. Fatkullin, Use of precipitate formation technology to increase oil recovery under, IOP Conference Series: Earth and Environmental Science, Vol. 87-5, 052001, 2017. 